\title{
Magnetic Affinity Cell Sorting
}

National Cancer Institute

\section{Source}

National Cancer Institute. Magnetic Affinity Cell Sorting. NCI Thesaurus. Code C116641.

A method of cell sorting that uses paramagnetic beads that are coated with antibodies, antigens, receptors, receptor substrates, binding proteins, etc to separate target cells from solution. 